\title{
Conjunctive uses of the geothermal water resources from lower cretaceous formations in the Mogilno-Lodz trough, Poland
}

\author{
Elzbieta Halaj ${ }^{1}$ (D) Beata Kepinska ${ }^{2}$
}

Received: 22 January 2018 / Accepted: 14 September 2018 / Published online: 26 September 2018

(c) The Author(s) 2018

\begin{abstract}
The geothermal energy sector continues to develop dynamically in the world. Within this work, preliminary feasibilities of different geothermal applications were presented for the Lower Cretaceous formations for wider geothermal uses' development in the Mogilno-Lodz trough, Central Poland. The Lower Cretaceous formations are one of the most prospective geothermal reservoirs in Central Poland. Geothermal waters that occur within them are mostly of $\mathrm{Na}-\mathrm{Cl}$ type and contain specific elements like I, $\mathrm{Br}$ or Fe. These are low-temperature geothermal resources together with highly variable mineralization, from 0.4 to even more than $90 \mathrm{~g} / \mathrm{L}$. A simple estimation procedure for hydrogeological information, such as water and thermal conditions of the reservoir obtained from an archival chemical analysis and borehole temperature loggings was developed. The potential for geothermal applications was estimated for three zones of the Mogilno-Lodz trough. Possibilities of conjunctive geothermal applications, such as space heating, balneotherapy and balneorecreation, mineral extraction, electricity production in binary systems and aquifer thermal energy storage were examined for the Lower Cretaceous formations.
\end{abstract}

Keywords Geothermal waters - The Lower Cretaceous aquifer · Low-temperature geothermal resources - Geothermal water applications $\cdot$ Renewable energy sources $\cdot$ Poland

\section{Introduction}

Geothermal resources are used worldwide in various ways. Different applications of geothermal water and energy in countries which have the biggest installed thermal capacity for direct use are shown in Table 1. All the listed countries also use geothermal source heat pumps installations, known as GSHP installations. GSHP installations have an important share in total thermal capacity for each country,

This article is part of the special issue on Sustainable Resource Management: Aqua.

Electronic supplementary material The online version of this article (https://doi.org/10.1007/s40899-018-0284-y) contains supplementary material, which is available to authorized users.

Elzbieta Halaj

ehalaj@agh.edu.pl

1 AGH University of Science and Technology, Mickiewicza 30 Ave., 30-059 Kraków, Poland

2 Mineral and Energy Economy Research Institute, Polish Academy of Sciences, Wybickiego 7A Str., 31-261 Kraków, Poland having mostly the biggest or even the only share (Finland) among different geothermal applications. Heat pumps constitute more than $70 \%$ of the installed capacity and more than 55\% of the annual energy use (Lund and Boyd 2016). The traditional direct geothermal applications such as bathing, (space or district) heating and agricultural or farming applications also play an important role in the use of geothermal resources. Apart from direct applications, there has been a growing interest in electricity production, especially in binary systems. More than a half of the newly installed plants in the last few years have been binary systems (Bertani 2016).

In Poland, geothermal energy uses are mostly for heating, bathing and swimming purposes, but the installed thermal capacity is lower than $500 \mathrm{MW}_{\mathrm{t}}$ (Lund and Boyd 2016). In several publications, the Mogilno-Lodz trough is considered a potential area for geothermal uses, especially for heating purposes (Bojarski et al. 1976; Gorecki 1995; Gorecki et al. 2006, 2015; Dowgiallo 2012; Dowgiallo et al. 2007). The most favourable formations are Lower Jurassic and Lower Cretaceous. Geothermal waters are currently used in some localities for heating, balneotherapeutical (Kepinska 2015, 2018) and recreational purposes (Halaj 2015). Generally, 
Table 1 Top ten countries in terms of installed thermal capacity and main applications of geothermal energy (based on Lund and Boyd 2016; Bertani 2016)

\begin{tabular}{|c|c|c|}
\hline Country & $\begin{array}{l}\text { Installed thermal } \\
\text { capacity for direct use } \\
\left(\mathrm{MW}_{\mathrm{t}}\right)\end{array}$ & Applications of geothermal energy in a given country \\
\hline China & $17,870.00$ & $\begin{array}{l}\text { GSHP, district heating, bathing and medical treatment, aquaculture facilities, industrial process heat, } \\
\text { greenhouse heating, agricultural drying, electricity production }\end{array}$ \\
\hline USA & $17,415.91$ & $\begin{array}{l}\text { GSHP, electricity production, fish farming, individual space heating, bathing and swimming, greenhouse } \\
\text { heating, district heating, agricultural drying, industrial process heating, snow melting, air conditioning }\end{array}$ \\
\hline Sweden & 5600.00 & GSHP, GSHP to district heating, ATES, BTES \\
\hline Turkey & 2886.30 & $\begin{array}{l}\text { Bathing and swimming, district heating, greenhouse heating, individual space heating, electricity produc- } \\
\text { tion, GSHP, agricultural drying }\end{array}$ \\
\hline Germany & 2848.60 & $\begin{array}{l}\text { GSHP, district heating, bathing and swimming, electricity production (only binary installations), indi- } \\
\text { vidual space heating }\end{array}$ \\
\hline France & 2346.90 & $\begin{array}{l}\text { GSHP, district heating, fish farming, bathing and swimming, electricity production, individual space } \\
\text { heating, greenhouse heating }\end{array}$ \\
\hline Japan & 2186.17 & $\begin{array}{l}\text { Bathing and swimming, electricity production, snow melting, GSHP, space heating, air conditioning, } \\
\text { greenhouse heating, fish farming, industrial applications }\end{array}$ \\
\hline Iceland & 2040.00 & $\begin{array}{l}\text { District heating, electricity production, snow melting, bathing and swimming, fish farming, industrial } \\
\text { process heat, greenhouse heating, GSHP }\end{array}$ \\
\hline Switzerland & 1733.08 & $\begin{array}{l}\text { GSHP (including geostructures, deep aquifers, tunnel water, etc.), bathing and swimming, fish farming, } \\
\text { district heating }\end{array}$ \\
\hline Finland & 1560.00 & GSHP \\
\hline
\end{tabular}

The countries are listed in a decreasing order of the installed thermal capacity

GSHP geothermal source heat pumps, ATES aquifer thermal energy storage, BTES borehole thermal energy storage

${ }^{a}$ Electricity production disregarded

it is also possible to use geothermal energy by applying groundwater heat pumps (Lo Russo et al. 2011; Lo Russo and Civita 2009) or ground source heat pumps (GSHP) (Luo et al. 2015), Enhanced Geothermal System (EGS) (Sowizdzal 2016) or to produce electricity using binary schemes (Wisniewski et al. 2011). Specifically, in the Mogilno-Lodz trough area, apart from bathing purposes, some new locations for geothermal space heating were considered as well as aquifer thermal energy storage (ATES), which was considered for one city in the area (Kepinska et al. 2017).

Currently, there are two geothermal centres in the study area which use geothermal waters from the Lower Cretaceous formations. The centres in Uniejow and Poddebice were commissioned in 2008 and 2013, respectively. The centre in Uniejow uses water from the depth of ca. $2000 \mathrm{~m}$. Its temperature is $68{ }^{\circ} \mathrm{C}$, while water mineralization is ca. 6-8 g/L. It is of Na-Cl type (Halaj 2015). Geothermal water is used for various purposes, including district heating, balneorecreational swimming pools and a geothermal health resort. In the centre in Poddebice, water is also exploited from the depth of ca. $2000 \mathrm{~m}$, but its mineralization is very low: only $0.4 \mathrm{~g} / \mathrm{L}$, while the temperature is $71^{\circ} \mathrm{C}$ (Kepinska et al. 2017). Geothermal water in Poddebice is used for heating purposes, in swimming pools and balneological treatment and it supplies a water drinking bar. There are recent plans to use geothermal water in a nearby zoo safari.
The aim of this work is to indicate the following possibilities and to determine the most prospective applications for the regions (zones) of the Mogilno-Lodz trough in the Lower Cretaceous formations, after comparing hydrogeological conditions (chemical parameters and thermal parameters of waters and of the reservoir). Similar analyses have been done previously for underlaying layers - the Lower Jurassic formations (Halaj 2018).

The depth of the Lower Cretaceous formations varies greatly. The temperature of a geothermal reservoir and water, which generally increases with depth according to a geothermal gradient, varies, respectively. Moreover, geological conditions, such as rocks' type, time of rock-water interaction or presence of salt structures can affect water parameters, i.e., mineralization or type of water, etc. It can be expected that waters of the Lower Cretaceous formations have different parameters, which make the Mogilno-Lodz trough a very good location for comprehensive use of geothermal water resources.

In this work, hydrogeological conditions are analysed and referred to the initial conditions, which should be taken into account while considering rational and sustainable use of several geothermal technologies. These initial conditions for direct use, aquifer thermal energy storage and minerals' extraction are temperature limits of water or medium, which determine the amount of obtained energy, minimum 
or maximum mineralization of water, which can affect transition system elements or determine if the water can be used directly or if there are minerals in amounts high enough to be cost-effectively extracted. To assess a geothermal potential for binary systems, the Underground Closed Geothermic Heat Exchanger technology is proposed. Several technical conditions for binary systems technology, such as the type and amount of working fluid or efficiency, are provided. To assess the regional ATES potential for the Mogilno-Lodz trough, parameters of water flow and reservoir dimensions are considered.

\section{Geological and hydrogeological settings}

The Mogilno-Lodz trough is located in Central Poland. The boundary of the trough is the study area boundary. It is defined by the bottom of the Lower Cretaceous formations. The area is ca. 20,000 $\mathrm{m}^{2}$. The area of the Mogilno-Lodz trough is shown in Fig. 1.
The Mogilno-Lodz trough is a structural unit (a synclinal structure, Fig. 2). The trough is located in Central Poland. It is formed by Triassic to Quaternary sediments. It is one of similar structures in the Polish Lowlands. The structure is asymmetric and founded on an epivariscan graben in the NW-SE direction. Alpine orogeny movements led to faulting of the trough area and created a number of grabens and horsts (Dadlez et al. 2000b; Dadlez 2001).

The thickness and the tectonic structure of the Lower Cretaceous section is affected by saline tectonics, such as other Mesozoic formations in the area. The top of the Lower Cretaceous formations is located at depths from $0 \mathrm{~m}$ up to $2300 \mathrm{~m}$. The Lower Cretaceous formations are composed mostly of permeable rocks, which are of $60-80 \%$ of the profile. The total thickness of water-bearing sediments differs according to the trough ranges between less than $25 \mathrm{~m}$ along the western part and $250 \mathrm{~m}$ along the eastern edges of the trough (Gorecki et al. 2006). The depth at which the Lower Cretaceous formations are located controls the reservoir temperature. The sedimentary sequence in the Lower

Fig. 1 Study area and location of analysed wells on the geological map (based on Dadlez et al. 2000a)

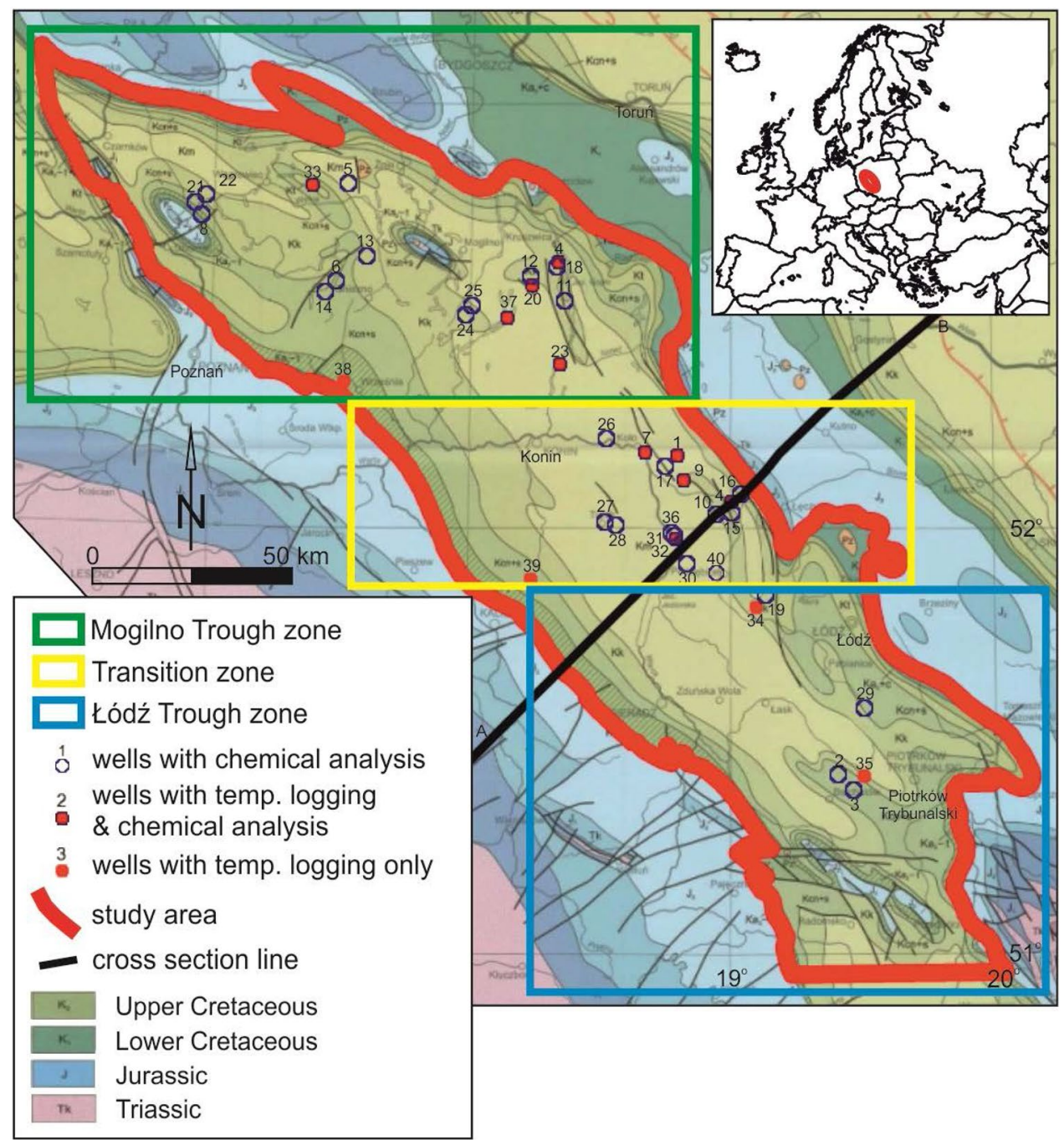


Fig. 2 Cross-section of the Mogilno-Lodz trough (without Quaternary formations) (Gorecki et al. 2006). Location of the cross-section line in Fig. 1

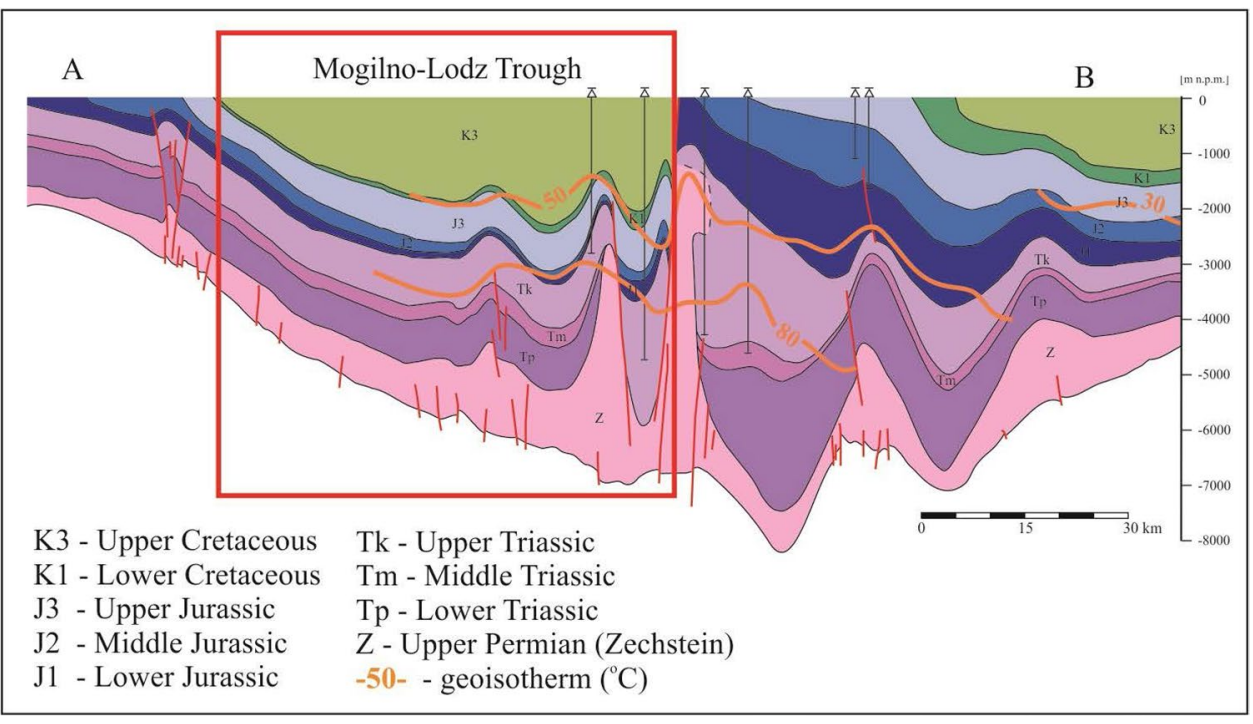

Cretaceous in the region is composed mainly of alternating complexes of sandstones, conglomerates, mudstones, claystones, marls and limestones. The Lower Cretaceous aquifer is of porous-fractured type and is composed of sediments, where sand, sandy carbonates and occasionally sandy mudstones predominate. Their effective porosity ranges from 3 to $45 \%$, mostly $15-25 \%$ (Gorecki 2006). They are interbedded with discontinuous series of semipermeable and impermeable formations (claystones and mudstones). Hydraulic conductivity of an underlying Jurassic aquifer and cracked Upper Cretaceous beds determines the recharge of the Lower Cretaceous aquifer. In the area, there is an increased value of hydraulic conductivity ranging from $4 \times 10^{-4}$ to $200 \times 10^{-5} \mathrm{~m}^{2} / \mathrm{s}$. Geothermal waters are under artesian pressure. For example, well no. 40 in Poddebice has water static table $26 \mathrm{~m}$ above ground level (Kepinska et al. 2017).

The main factor triggering formation of the present structure of the Permian-Mesozoic complex was vertical block movements of the pre-Zechstein bedrock (Palaeozoic formations), followed by deformations resulting from movements of the Zechstein (Upper Permian) mass of salt (Gorecki et al. 2006). There are numerous salt structures, which penetrate partially or completely the Mesozoic formations. These structures occur mainly in the northeastern and in the northern part of the trough and continue to the east. Salt structures have an impact on water type and its chemical composition. And an anomalous heat flow occurrence is observed over salt domes (Petersen and Lerche 1995).

\section{Materials and methods}

To find the conditions of the Lower Cretaceous formations, archival data from 150 wells from the Mogilno-Lodz trough were analysed. Sample-related data is based on archival data (drillings documentation, chemical analyses, temperature loggings) collected from the National Geological Archives, the Archives of Department of Fossil Fuels, AGH University of Science of Technology and Archives of Geotermia Poddebice Sp. z o. o. The samples were collected mostly during drillings made in 1960s and 1970s. Many wells are nowadays abandoned. Wells analysed within this research are mostly deep drillings, excluding shallow wells less than $200 \mathrm{~m}$ of depth. 40 wells with Lower Cretaceous sections, water occurrence, mineralization examination and at least major ion content were selected. The location of the selected wells is shown in Fig. 1. The wells were gathered into three groups/zones, according to their geographical distribution. They were named the Mogilno trough (located in the northwest of the trough), the Lodz trough (located in the southern part of the trough) and a transition zone (located in between). Apart from geographical distribution, samples from a particular zone may present similar parameters, such as the proportion of major ion content or water type, even a different mineralization level. The water samples from the archival analysis were taken from an interval of depth, thus, to compare samples, the depth of the top of the sampled interval is provided.

Geological examination of the area was carried out mostly during deep drillings in search of hydrocarbons. Therefore, geothermal or water parameters were not of the main interest and sometimes data is very limited. There are 14 wells with borehole temperature loggings. In three of them, there is no water examination data available. In the remaining wells, at least mineralization and major ion content are examined. The top of sampling intervals in the wells lies between 208 and $2448 \mathrm{~m}$ below ground level.

One of the most important aspects is temperature. According to archival reports, borehole temperature loggings were done after several days of stopping drilling 
or mud circulation to stabilize thermal conditions in the wells and their ambient rock formations. However, time passed since stopping drilling works or mud circulation might be in some cases too short to reach thermal equilibrium among the wells, ambient rock formations and aquifers. Therefore, some temperature loggings were taken in quasi-stable thermal conditions (especially if mud losses or reservoir water inflows were recorded during or after drillings). Water temperatures available from archival data were measured at the outflow of the well or in the ceiling of the sampled interval. Vertical changeability of the geothermal gradient in the Lower Cretaceous section was compared with the geothermal gradient calculated for the whole well and the average geothermal gradient for the Polish Lowlands (the principal geological unit for Lower Cretaceous).

The local geothermal gradient for the whole well length and for the Lower Cretaceous section was calculated according to the following formula (Plewa 1994):

$G=\operatorname{grad} T=\frac{T_{2}-T_{1}}{h_{2}-h_{1}}$,

where $T_{1}, T_{2}$-temperature in ${ }^{\circ} \mathrm{C}$ at $h_{1}$ and $h_{2}$ depths, $h_{1}$, $h_{2}$-depth in $\mathrm{m}$.

Thermal data obtained from temperature loggings is available for 14 wells. The maximum depth of a single well is $3500 \mathrm{~m}$. The registered temperatures for those wells range from dozens to over $135{ }^{\circ} \mathrm{C}$. In two cases (wells no. 9 and 34), temperature loggings were done in unstable conditions, which was best visible in sections located below $1500 \mathrm{~m}$. Such logs were not taken into calculations and are not shown. Another temperature profile does not include the Cretaceous layers, which are located much deeper. It was assumed that temperature at depths corresponding to the Cretaceous layers is even higher than last temperature record value. In this case, only gradients for the whole curve were calculated.

The geothermal gradient value for curves with interval or discontinuous measurements was averaged according to the formula:

$G_{\text {av. }}=\frac{G_{1} h_{1}+G_{2} h_{2}+\cdots+G_{n} H_{n}}{\sum_{i=1}^{n} h_{i}}$,

where $G_{1}, G_{2}, \ldots G_{n}$-interval geothermal gradient values on the section of the thickness $h_{1}, h_{2}, \ldots, h_{n}$.

The highest values of the expected temperatures are considered in terms of electricity production in binary systems. For the best result, an Underground Closed Geothermic Heat Exchanger on isobutane base (described by Kaczmarek 2011) was chosen. This method guarantees electricity production at a very low temperature, i.e.,
$80{ }^{\circ} \mathrm{C}$. The application of $1 \mathrm{~kg} / \mathrm{s}$ of working medium, $80{ }^{\circ} \mathrm{C}$ of evaporation temperature and $30{ }^{\circ} \mathrm{C}$ of condensation temperature is considered. One of the lowest geothermal water temperatures used in binary systems is $73{ }^{\circ} \mathrm{C}$ in Chena Hot Springs, Alaska, USA (Taylor et al. 2013; Erkan et al. 2008; Lund 2006). That reference temperature has been compared with thermal conditions in the study area.

Electric power $\left(N_{\mathrm{el}}\right)$ was calculated according to the following formula (after Kaczmarek 2011):

$N_{\mathrm{el}}=N_{\mathrm{CR}} \eta_{\mathrm{i}} \eta_{\mathrm{m}} \eta_{\mathrm{g}}$,

where:

$N_{\mathrm{CR}}=\dot{m}_{\mathrm{n}}\left[\left(h_{1}-h_{2 \mathrm{~s}}\right)-\left(h_{4 \mathrm{~s}}-h_{3}\right)\right]$.

Thus, the following parameters are assumed: mass flux of working medium $\left(\dot{m}_{n}=1 \mathrm{~kg} / \mathrm{s}\right)$, internal turbine - set performance $\left(\eta_{\mathrm{i}}=0.75\right)$, mechanical performance $\left(\eta_{\mathrm{m}}=0.97\right)$, electric generator performance $\left(\eta_{\mathrm{g}}=0.96\right)$ and $h_{1}, h_{2 \mathrm{~s}}, h_{3}, h_{4 \mathrm{~s}}$ (thermodynamic cycle points).

The most crucial parameters for balneotherapeutical and recreational use of geothermal water are water temperature and proper chemical composition, such as content of I, Fe and sometimes $\mathrm{Br}$ ions.

Some basic geological parameters, such as type and depth of the formation, water flow rate in the aquifer, reservoir thickness or temperature conditions, which determine the use of an aquifer as a heat accumulator, were set to evaluate the ATES potential. These parameters come mostly from the results of geothermal potential modelling made by Gorecki et al. (2006). Potential areas are shown rather than detailed analyses for specific locations. Only general possibilities of use have been shown, which should be verified in detail before starting any investment. The obtained results can point to the way in which geothermal resources in the area should be used in a sustainable way as well as where to expect waters suitable for specific and the most popular uses.

\section{Results}

\section{Hydrogeological and hydrogeochemical parameters}

According to the analysis of archival data, in the area of the Mogilno-Lodz trough, in the Lower Cretaceous formations, waters are mostly of the $\mathrm{Na}-\mathrm{Cl}$ type. The main type of waters and their mineralization, as well as the depth of the top of the sampled interval are presented in Table 2 . Wells are listed in increasing depths of the top of the sampled interval in each zone. The mineralization of waters ranges from 0.2 to $100.8 \mathrm{~g} / \mathrm{L}$. The lowest mineralization values occurred in the Lodz Zone. The mineralization is low, these are fresh waters and their mineralization does not 
Table 2 Hydrochemical parameters of waters from the Lower Cretaceous formations in the Mogilno-Lodz trough

\begin{tabular}{|c|c|c|c|c|}
\hline Well ID & $\begin{array}{l}\text { Depth of the top } \\
\text { of the sampled } \\
\text { interval (m bgl) }\end{array}$ & $\begin{array}{l}\text { Miner- } \\
\text { alization } \\
(\mathrm{g} / \mathrm{L})\end{array}$ & Water type & Zone \\
\hline 6 & 208 & 2.2 & $\mathrm{Na}-\mathrm{Cl}-\mathrm{HCO}_{3}$ & MT \\
\hline 22 & 278 & 1.9 & $\mathrm{Na}-\mathrm{Ca}-\mathrm{Cl}$ & MT \\
\hline 14 & 295 & 1.1 & $\mathrm{Na}-\mathrm{Cl}$ & MT \\
\hline 33 & 407 & 3.4 & $\mathrm{Na}-\mathrm{Cl}$ & MT \\
\hline 21 & 518 & 1.8 & $\mathrm{Na}-\mathrm{Cl}$ & MT \\
\hline 11 & 635 & 35.0 & $\mathrm{Na}-\mathrm{Cl}$ & MT \\
\hline 18 & 714 & 37.8 & $\mathrm{Na}-\mathrm{Cl}$ & MT \\
\hline 13 & 717 & 11.8 & $\mathrm{Na}-\mathrm{Cl}$ & MT \\
\hline 8 & 825 & 5.3 & $\mathrm{Na}-\mathrm{Cl}$ & MT \\
\hline 4 & 910 & 41.0 & $\mathrm{Na}-\mathrm{Cl}$ & MT \\
\hline 20 & 1037 & 26.1 & $\mathrm{Na}-\mathrm{Cl}$ & MT \\
\hline 20 & 1120 & 34.4 & $\mathrm{Na}-\mathrm{Cl}$ & MT \\
\hline 12 & 1150 & 29.4 & $\mathrm{Na}-\mathrm{Cl}$ & MT \\
\hline 20 & 1235 & 35.4 & $\mathrm{Na}-\mathrm{Cl}$ & MT \\
\hline 24 & 1295 & 37.1 & $\mathrm{Na}-\mathrm{Cl}$ & MT \\
\hline 25 & 1310 & $\mathrm{n} / \mathrm{a}$ & $\mathrm{Na}-\mathrm{Cl}$ & MT \\
\hline 20 & 1324 & 32.0 & $\mathrm{Na}-\mathrm{Cl}$ & MT \\
\hline 5 & 2060 & 100.8 & $\mathrm{Na}-\mathrm{Cl}$ & MT \\
\hline 23 & 2386 & 93.5 & $\mathrm{Na}-\mathrm{Cl}$ & MT \\
\hline 37 & 2448 & 93.0 & $\mathrm{Na}-\mathrm{Cl}$ & MT \\
\hline 28 & 1215 & 3.0 & $\mathrm{Na}-\mathrm{Cl}$ & $\mathrm{TZ}$ \\
\hline 27 & 1356 & 11.0 & $\mathrm{Na}-\mathrm{Cl}$ & $\mathrm{TZ}$ \\
\hline 30 & 1719 & 21.0 & $\mathrm{n} / \mathrm{a}$ & $\mathrm{TZ}$ \\
\hline 10 & 1728 & 2.2 & $\mathrm{Na}-\mathrm{Cl}-\mathrm{HCO}_{3}$ & $\mathrm{TZ}$ \\
\hline 17 & 1751 & 9.1 & $\mathrm{Na}-\mathrm{Cl}$ & $\mathrm{TZ}$ \\
\hline 9 & 1773 & 7.6 & $\mathrm{Na}-\mathrm{Cl}$ & $\mathrm{TZ}$ \\
\hline 10 & 1865 & 2.1 & $\mathrm{Na}-\mathrm{Cl}$ & $\mathrm{TZ}$ \\
\hline 32 & 1898 & 6.8 & $\mathrm{Na}-\mathrm{Cl}$ & $\mathrm{TZ}$ \\
\hline 31 & 1918 & 7.4 & $\mathrm{Na}-\mathrm{Cl}$ & $\mathrm{TZ}$ \\
\hline 36 & 1927 & 9.2 & $\mathrm{Na}-\mathrm{Cl}$ & $\mathrm{TZ}$ \\
\hline 40 & 1967 & 0.4 & $\mathrm{Na}-\mathrm{Ca}-\mathrm{HCO}_{3}$ & $\mathrm{TZ}$ \\
\hline 26 & 1996 & 90.0 & $\mathrm{Na}-\mathrm{Cl}$ & $\mathrm{TZ}$ \\
\hline 16 & 2110 & 74.2 & $\mathrm{Na}-\mathrm{Cl}$ & $\mathrm{TZ}$ \\
\hline 15 & 2150 & 25.1 & $\mathrm{Na}-\mathrm{Cl}$ & $\mathrm{TZ}$ \\
\hline 1 & 2182 & 57.8 & $\mathrm{Na}-\mathrm{Cl}$ & $\mathrm{TZ}$ \\
\hline 7 & 2438 & 94.7 & $\mathrm{Na}-\mathrm{Cl}$ & $\mathrm{TZ}$ \\
\hline 3 & 538 & 0.5 & $\mathrm{Na}-\mathrm{Ca}-\mathrm{HCO}_{3}$ & LT \\
\hline 2 & 582 & 0.3 & $\begin{array}{l}\mathrm{Na}-\mathrm{Ca}-\mathrm{HCO}_{3}- \\
\mathrm{SO}_{4}\end{array}$ & LT \\
\hline 29 & 760 & 0.2 & $\mathrm{Ca}-\mathrm{Na}-\mathrm{HCO}_{3}$ & LT \\
\hline 34 & 1478 & 0.4 & $\mathrm{Ca}-\mathrm{Na}-\mathrm{HCO}_{3}$ & LT \\
\hline 19 & 1607 & 0.4 & $\mathrm{Na}-\mathrm{Ca}-\mathrm{HCO}_{3}$ & LT \\
\hline
\end{tabular}

Wells in the table are listed according to an increasing depth of the top of the sampled interval in each zone: $M T$ Mogilno trough, $L T$ Lodz trough, $T Z$ transition zone. Well ID according to Fig. 1

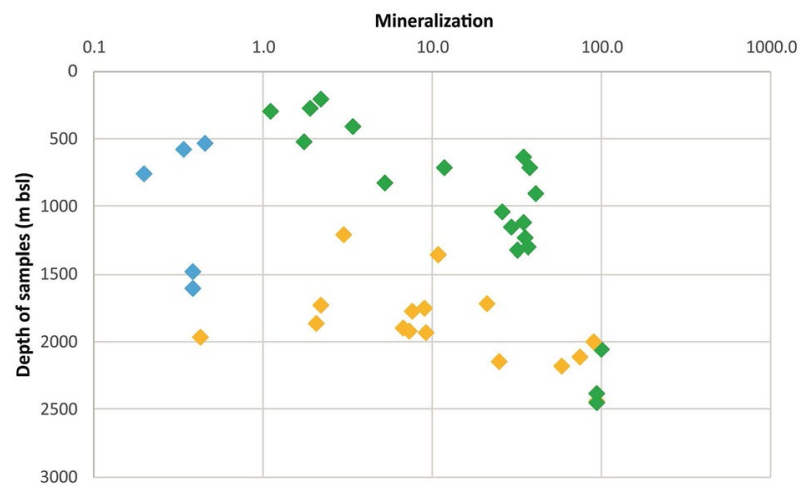

Fig. 3 Dependence between water mineralization from the Lower Cretaceous formations and depth of the top of the sampled interval (green - the Mogilno trough, yellow-the transition zone, blue-the Lodz trough)

exceed $0.5 \mathrm{~g} / \mathrm{L}$. It is interesting, that such low mineralization occurred at great depth, even to ca. $1600 \mathrm{~m}$ (e.g., well no. 19). Waters from Lodz trough are $\mathrm{Na}-(\mathrm{Ca})-\mathrm{HCO}_{3}$ waters, which distinguishes them from waters from other zones. The mineralization of the Mogilno trough and the transition zone (northern and central part of the trough) is higher than mineralization in the Lodz trough. In the Mogilno trough and the transition zone, waters of $\mathrm{Na}-\mathrm{Cl}$ type prevail. Only in samples with mineralization of ca. $2 \mathrm{~g} / \mathrm{L}$, waters differ and are of $\mathrm{Na}-(\mathrm{Ca})-(\mathrm{Cl})-\mathrm{HCO}_{3}$ type.

No clear vertical distribution of water mineralization is noticeable. Waters with the highest mineralization (over $90 \mathrm{~g} / \mathrm{L}$ ) occur at the deepest depths exceeding ca. $2000 \mathrm{~m}$. Generally, mineralization increases with depth, but numerous exceptions can be observed. One example may be an unexpectedly low mineralization of water $(0.4 \mathrm{~g} / \mathrm{L})$ extracted from the depth of ca. $2000 \mathrm{~m}$ (well no. 40).

Figure 3 presents vertical distribution of water mineralization in different zones. There are waters from greater depths that still have low mineralization. For example, waters with mineralization up to $5 \mathrm{~g} / \mathrm{L}$ occurred at depth of even $2000 \mathrm{~m}$ in the Lodz trough and in the transition zone.

All samples from the southern part of the area have mineralization below $0.5 \mathrm{~g} / \mathrm{L}$. The central part of the trough area (the transition zone) is characterized by significant differences in mineralization, ranging between 0.4 and $94.7 \mathrm{~g} / \mathrm{L}$, and the samples come from depths of 1200-2400 m. Only in the northern part of the trough (the Mogilno trough), water mineralization increases proportionally to depth in the range of $1.1-100.8 \mathrm{~g} / \mathrm{L}$ at depths of $200-2400 \mathrm{~m}$.

The mineralization of the sample from the transition zone mentioned before is unexpectedly low and it amounts to $0.4 \mathrm{~g} / \mathrm{L}$, despite coming from the depth of $1967 \mathrm{~m}$. The samples from adjacent areas and from similar depths show certainly higher mineralization values, usually more than $7 \mathrm{~g} / \mathrm{L}$. This sample has a high temperature of $71^{\circ} \mathrm{C}$ and a 
unique water type in comparison to other samples. It is of $\mathrm{Na}-\mathrm{Ca}-\mathrm{HCO}_{3}$ water type. Adjacent samples are all of the $\mathrm{Na}-\mathrm{Cl}$ type. From the hydrogeological point of view, this sample is more likely to belong to the Lodz trough, where all samples are of $\mathrm{Na}-\mathrm{Ca}-\mathrm{HCO}_{3}$ or $\mathrm{Ca}-\mathrm{Na}-\mathrm{HCO}_{3}$ type. It is possible, that there is a lateral flow of water of a different type to the well.

Water from this sample is used in a geothermal heating plant commissioned in 2013 and a geothermal swimming pool. The water was expected to have much higher mineralization of about $8-13 \mathrm{~g} / \mathrm{L}$ (Kepinska et al. 2017), but a pumping test made after drillings showed much lower mineralization. The present and the future geothermal water use from the well may become one of the model solutions for sustainable geothermal water use in Poland.

The Schoeller's diagram (Schoeller 1962) shows the content of main ions from all considered zones (Fig. 4). Waters from the transition zone (Fig. 4b) demonstrate similar characteristics. The notable exception is the above-mentioned sample, detached from other samples and marked with red in the diagram. In the Mogilno trough (Fig. 4a), greater differences of major ions can be observed; however, waters demonstrate peaks of cations similar to the transition zone (Fig. 4b). In both zones, waters have similar chemical characteristics, with $\mathrm{Na}>\mathrm{Ca}>\mathrm{Mg}$ and $\mathrm{Cl}>\mathrm{SO}_{4}>\mathrm{HCO}_{3}$ in the Mogilno trough and $\mathrm{Cl}>\mathrm{HCO}_{3}>\mathrm{SO}_{4}$ in the transition zone. Waters from the Lodz trough (Fig. 4c) have completely different characteristics of major ions. Waters from the Mogilno trough and the transition zone are chloride waters, while waters in the Lodz trough are bicarbonate waters.

\section{Specific elements}

Waters from the Lower Cretaceous formations contain elements, which could be used for balneoterpeutic purposes, namely iron (Fe), iodine (I) and bromine (Br). The minimum ion content is shown in Table 3 . The content of the elements higher than the minimum limit allow waters to be called ferruginous waters and iodide waters, respectively, and, what is more important, they can be called medicinal (therapeutic) waters (Dz.U.2018.605). In case of bromine, the content from the previous legislation is given. It is presented only for information purposes. Currently, bromine is excluded from the Polish law, because of the Recommendation of the Polish Association of Balneology and Physical Medicine which states that water may not have a therapeutic effect in a given concentration (Polish Association of Balneology and Physical Medicine 2016). There is no maximum concentration for those elements given in the Decree of the Ministry of Health (Dz.U.2018.605). The content of Fe, I and Br ions and their depth of occurrence is shown in Fig. 5. Not all of the available samples were examined for $\mathrm{Fe}$, I and $\mathrm{Br}$ contents.
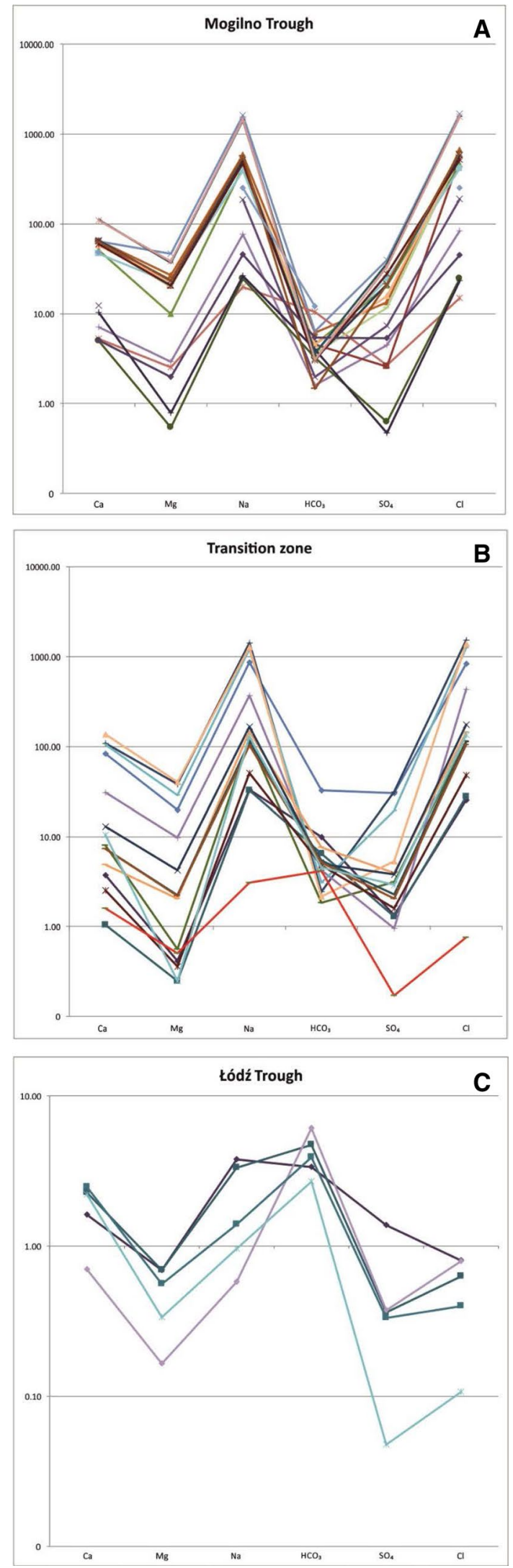

Fig. 4 Semi-logarithmic Schoeller's diagrams of waters from the three zones: the Mogilno trough (a), the Lodz trough (c) and the transition zone (b). Concentration of ions is expressed in meq/L 
Table 3 Selected medicinal specific components in waters for treatment purposes (Decree of the Ministry of Health, Dz.U.2018.605)

\begin{tabular}{lc}
\hline Medicinal specific component & $\begin{array}{l}\text { Minimum concen- } \\
\text { tration level }(\mathrm{mg} / \mathrm{L})\end{array}$ \\
\hline Iodide & $\mathbf{1}$ \\
Sulphides & 1 \\
Fluorides & 2 \\
Iron & $\mathbf{1 0}$ \\
Bromide $^{\mathrm{a}}$ & $\mathbf{5}$ \\
\hline
\end{tabular}

Concentration of components for the Mogilno-Lodz trough provided in bold

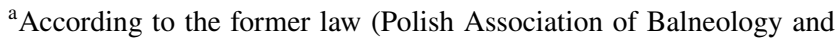
Physical Medicine 2016)

The iron (Fe) ion content is, in most cases, low and does not exceed the limit of $10 \mathrm{mg} / \mathrm{L}$. Higher values occur in the transition zone, where waters can be of medicinal relevance. The content of iron ions which may have therapeutic use ranges mostly from 16 to $26 \mathrm{mg} / \mathrm{L}$, and $120 \mathrm{mg} / \mathrm{L}$ in one deep well, where water comes from ca. $2200 \mathrm{~m}$.

In the area of the Lodz trough, iodine (I) is not present $(0 \mathrm{mg} / \mathrm{L})$. In the area of the Mogilno trough and the transition zone, iodine ions content is above the legal limits. Therefore, a great number of waters might be called iodide waters, and depending on other parameters, they can be used in medicine. In the Mogilno trough area, the content of iodides increases proportionately to depth. Content variations are very small. The samples' depth ranges from 900 to $2500 \mathrm{~m}$, while iodine ions' content ranges from 1.5 to $3.6 \mathrm{mg} / \mathrm{L}$. In the transition zone area, where waters come from greater depths, $3-12.8 \mathrm{mg} / \mathrm{L}$ of iodine ions are noted at depths of 2100-2400 m.

There is only one sample of $\mathrm{Br}$ from the area of the Lodz trough, but with a shortage of bromine ions. Other samples from the Mogilno trough and the transition zone often exceed the bromine lower limit of $5 \mathrm{mg} / \mathrm{L}$. The content of bromine ions over the limit ranges from 6.6 to $86 \mathrm{mg} / \mathrm{L}$, and samples come from different depths of 400-2448 m. In the transition zone, bromide occurs deeper, at depths of 1700-2200 m. Nevertheless, its content is lower. Close to the limit, the content of bromine ions ranges from 5.36 to $45 \mathrm{mg} / \mathrm{L}$.

\section{Thermal parameters}

Data from borehole temperature loggings of the Lower Cretaceous formations come from depths of 137-2647 m. Registered temperatures in the Lower Cretaceous formations range from 17.9 to $82.9^{\circ} \mathrm{C}$. The highest temperature of $82.9^{\circ} \mathrm{C}$ was registered at the depth of $2435 \mathrm{~m}$. The diagram of temperature profiles, drawn from archival geophysical
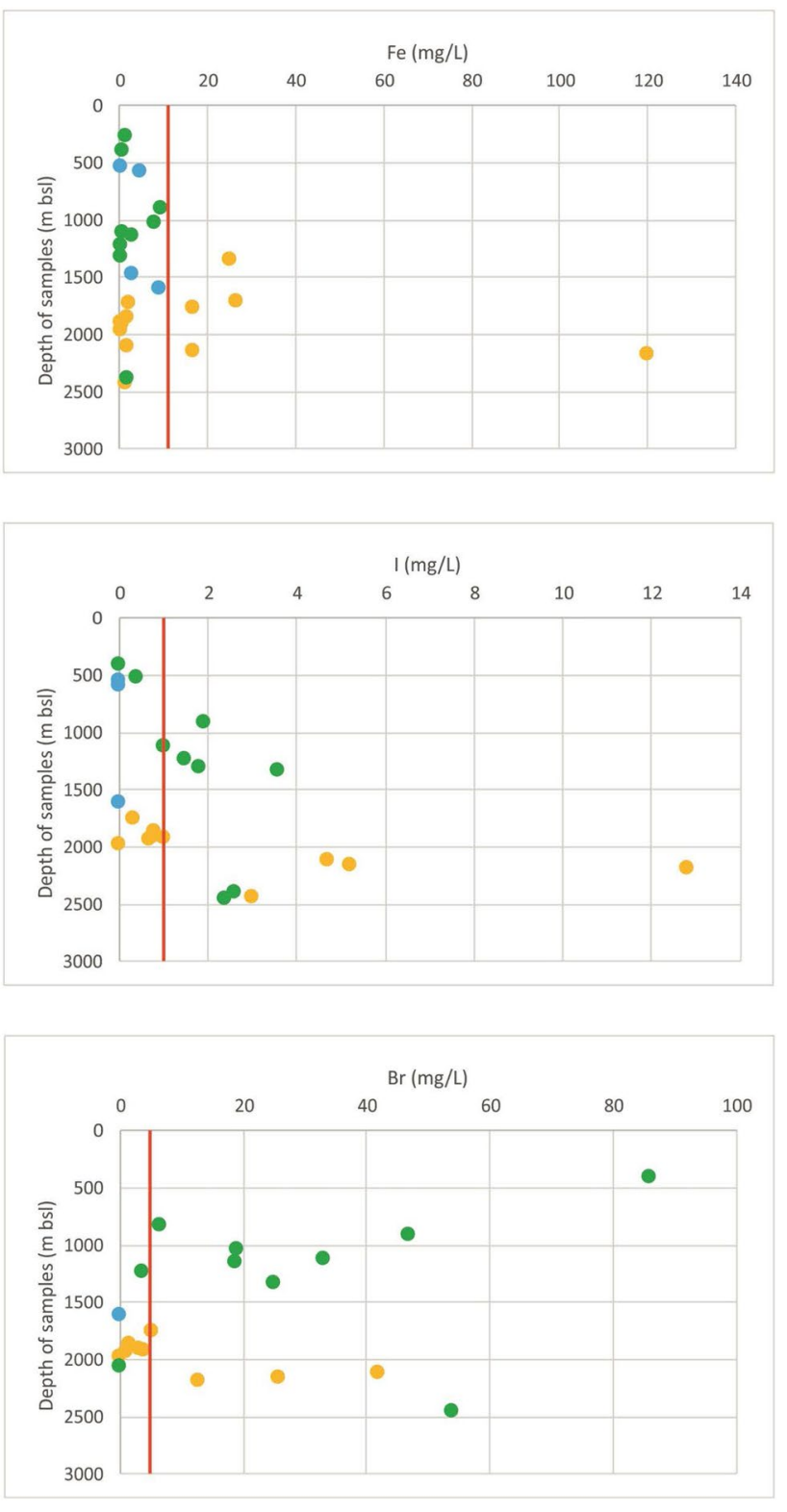

Fig. 5 Relationship between the concentration of balneotherapyrelated ions ( $\mathrm{Fe}, \mathrm{I}, \mathrm{Br})$ and depth. The red line shows the minimum concentration of elements for balneotherapeutical purposes (according to the Decree of the Ministry of Health, Dz.U.2018.605 and the Polish Association of Balneology and Physical Medicine 2016). Colours: green - the Mogilno trough, yellow-the transition zone, blue - the Lodz trough

data is shown in Fig. 6, under quasi-stable conditions assumed. The highest temperature occurred in the deepest zones, particularly in the Mogilno trough and the transition zone.

An average geothermal gradient for the Polish Lowlands (the principal unit for the Mogilno-Lodz trough) is $2.5{ }^{\circ} \mathrm{C} / 100 \mathrm{~m}$ (Szewczyk and Hajto 2006). The local geothermal gradient (Table 4) is calculated according to (1) and 


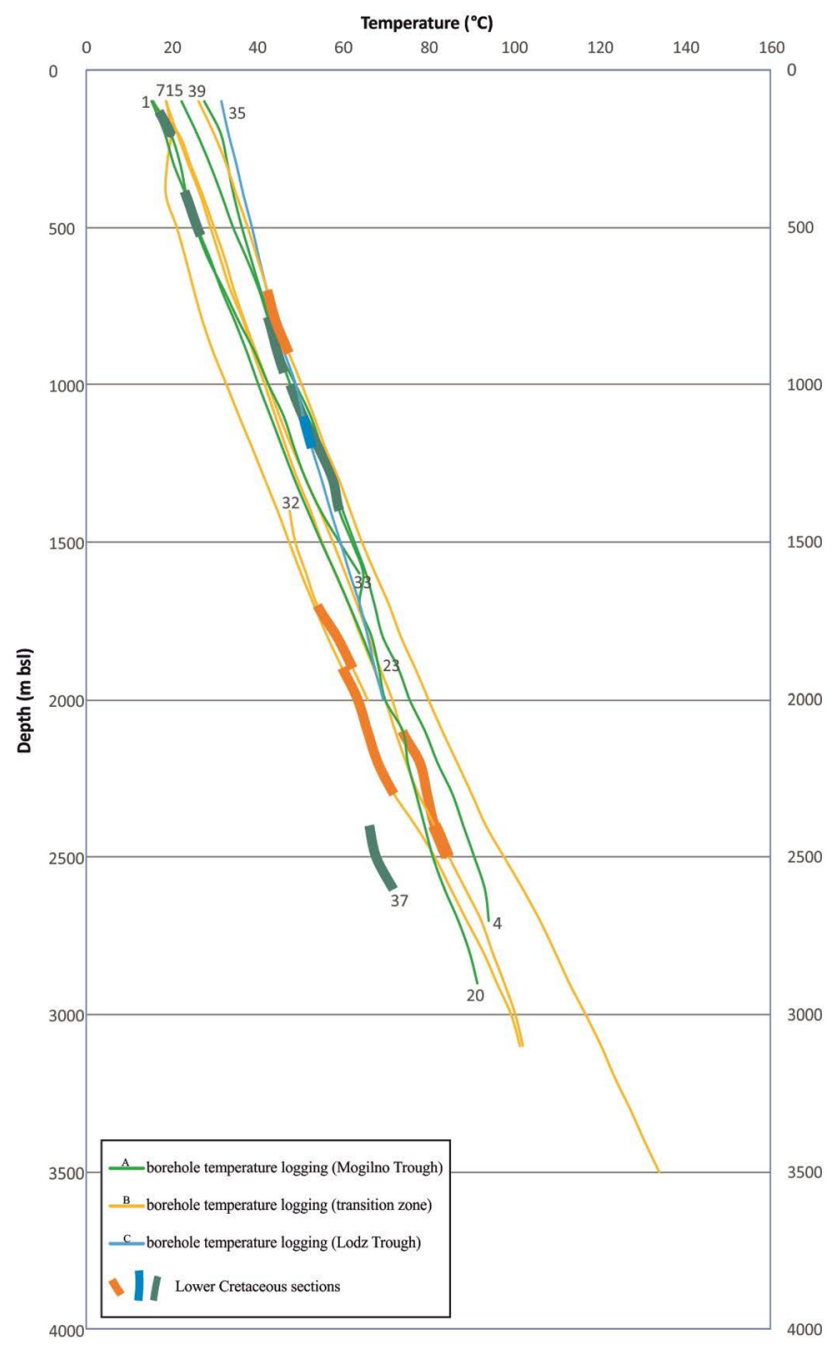

Fig. 6 Relationship between temperature records and the depth of the sampled interval separated into three zones of the Mogilno-Lodz trough with a specific reference to the Lower Cretaceous formations. Data from archival borehole temperature loggings in the area of Mogilno-Lodz trough. Well numbers according to Fig. 1

(2) formula. The local geothermal gradient of the Lower Cretaceous formations ranges from 1.8 to $3.2{ }^{\circ} \mathrm{C} / 100 \mathrm{~m}$, with $2.5 / 100 \mathrm{~m}$ average. In some cases, this gradient is higher than the gradient for the whole curve. An average gradient for the curves is $2.8^{\circ} \mathrm{C} / 100 \mathrm{~m}$. The highest value of the geothermal gradient is $3.2{ }^{\circ} \mathrm{C} / 100 \mathrm{~m}$ (in two wells from the Mogilno trough and the transition zone) and it is most probably connected to salt domes.

In case of geothermal water, the highest temperature is most desirable, also when considering cascaded systems. However, as water temperature rises, which is commonly related to an increase in depth, mineralization rises as well. Figure 7 shows the relation between mineralization and water temperature.
In the transition zone, temperature at the outflow is the highest and mineralization is low at the same time (apart from one sample). Temperature is $40-70{ }^{\circ} \mathrm{C}$, respectively, and mineralization is mostly $0.5-10$ (max. 20 and 95) g/L. The samples from the Mogilno trough demonstrate rather unfavourable conditions. The samples are distributed into two groups: one group with mineralization of $26-35 \mathrm{~g} / \mathrm{L}$ and temperature of $25-29{ }^{\circ} \mathrm{C}$, and the other group with very high mineralization and temperature: ca. $93-100 \mathrm{~g} / \mathrm{L}$ and $50-70{ }^{\circ} \mathrm{C}$, respectively. In case of the Lodz trough, there is only one sample with temperature measured at the outflow, but having not favourable parameters: low mineralization, accompanied by low temperature of ca. $25^{\circ} \mathrm{C}$.

All samples were divided according to their geographical location. In a part of the diagram with the highest temperature and mineralization shown in Fig. 7, there are three samples from the Mogilno trough and one from the transition zone. All samples come from the depth of more than $2000 \mathrm{~m}$. After the analysis conducted, we know that despite the sample (a circle with a green border) coming from a remote part of the transition zone, it has similar chemical composition, water type and a mineralization level to the samples from the Mogilno trough (cf. Fig. 4). This sample is from well no. 7 (cf. Table 2). This may be caused by influence of salt structures located in the area and/or by faults thanks to which water with higher mineralization is transported.

From a hydrochemical point of view, the sample can be classified as a Mogilno trough sample. However, it is important to remember about a possibility that there are waters with different parameters in the area.

Similarly, the sample from well no. 40 (a circle with a blue border) has water type and mineralization which is more similar to samples from the Lodz trough than the transition zone (cf. Fig. 4). It can be also classified to the Lodz trough from a hydrochemical point of view.

If we allocate the samples to the zones according to their water mineralization values and types, the correlation of water temperature and mineralization diagram is as in Fig. 7 (allocated samples marked with a circle). According to Fig. 7, the best conditions for geothermal water exploitation are in the transition zone. Waters temperature in comparison to their mineralization is growing faster in the transition zone than in the Mogilno trough and the water is much less mineralized there.

\section{Discussion}

The collected data were analysed in terms of mineralization, main components, water type and reservoir temperature. The changeability and relation of several parameters (mineralization, thermal parameters, specific components content) 
Table 4 Geothermal gradient values calculated on the basis of temperature profiles for the Lower Cretaceous sections based on formula (1) and (2) assuming the conduction of heat transfer

\begin{tabular}{lllll}
\hline Well ID & $\begin{array}{l}\text { Depth of the top of the Lower } \\
\text { Cretaceous formation }(\mathrm{m} \mathrm{bsl})\end{array}$ & $\begin{array}{l}\text { Temperature logging result at } \\
\text { the top of the formation }\left({ }^{\circ} \mathrm{C}\right)\end{array}$ & $\begin{array}{l}\text { Local geothermal gradient } \\
(\operatorname{grad}) \text { for the whole well } \\
\left({ }^{\circ} \mathrm{C} / 100 \mathrm{~m}\right)\end{array}$ & $\begin{array}{l}\text { Local geothermal gradient }(\mathrm{grad} T) \\
\text { in Lower Cretaceous formations } \\
\left({ }^{\circ} \mathrm{C} / 100 \mathrm{~m}\right)\end{array}$ \\
\hline 1 & 2181.5 & 77.35 & 2.9 & 2.2 \\
4 & 916.5 & 43.00 & 2.8 & 3.2 \\
7 & 2435.0 & 75.90 & 2.8 & 1.9 \\
9 & 1776.0 & 46.54 & 3.0 & $\mathrm{n} / \mathrm{a}$ \\
15 & 1960.5 & 61.66 & 2.8 & 2.8 \\
20 & 1037.5 & 42.66 & 2.3 & $\mathrm{n} / \mathrm{a}$ \\
23 & 2388.0 & $>67.56$ & 2.9 & 3.2 \\
32 & 1897.1 & 62.19 & 3.0 & 2.3 \\
33 & 390.0 & 23.15 & 3.2 & 2.1 \\
34 & 1478.0 & 26.88 & 2.2 & $\mathrm{n} / \mathrm{a}$ \\
35 & 1104.0 & 50.99 & 2.0 & 2.9 \\
37 & 2422.5 & 66.50 & 2.8 & 1.8 \\
38 & 137.0 & 17.90 & 3.4 & 2.3 \\
39 & 785.0 & 44.06 & 3.2 & 2.5 \\
\hline
\end{tabular}

Well numbers according to Fig. 1

$n / a$ not available

with the depth of a sampled interval was analysed. Chemical components have been considered mainly in terms of using geothermal waters in balneotherapy and recreation, as well as for heating purposes. In case of balneotherapeutical purposes, the content of some specific components ( $\mathrm{Fe}, \mathrm{I}$, $\mathrm{Br}$ ) was also considered.

According to Axelsson (2010), there are two sustainable geothermal energy uses: sustainable geothermal production, concerning maintaining production from a single system and

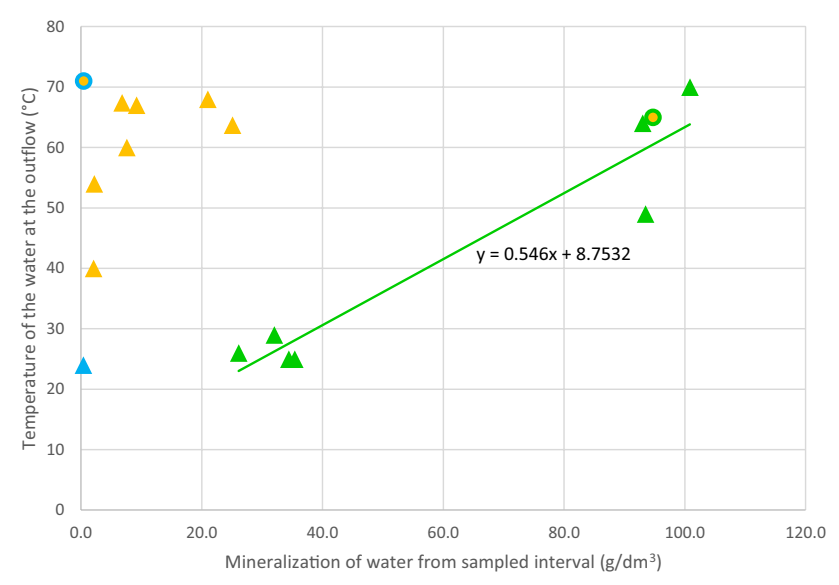

Fig. 7 Correlation of water temperature at the outflow and water mineralization in the sampled interval. All waters samples were taken from the Lower Cretaceous formations of the Mogilno-Lodz trough (green - the Mogilno trough, yellow-the transition zone, blue-the Lodz trough, circles - allocated samples) sustainable geothermal use, involving integrated economic, social and environmental development. A recharge and discharge balance, overproduction and a cold-front breakthrough are discussed in several papers (Szanyi and Kovács 2010; Axelsson 2010; Buday et al. 2015). Another issue is to maximize utilisation of available resources, which should be considered in the study area.

Direct applications of geothermal energy is the most versatile form of using geothermal energy of low enthalpy (Rubio-Maya et al. 2015). The best way to maximize the use of medium or low enthalpy geothermal resources is to use them in cascades for direct use and, if possible, electricity production. The concept of cascade use is harnessing of geothermal heat at different thermal levels in sequential processes. The cascade system can include electricity production or thermal uses only (Rubio-Maya et al. 2015). Another example may be multiple use of geothermal energy or heat storage for increasing the efficiency of heating or for better incorporation of renewable energy sources, which are very variable.

According to the results of this work in the area of the Mogilno-Lodz trough in the Lower Cretaceous formations, there are low enthalpy geothermal conditions and varied mineralization of water. Some proposed applications for the respective trough zones are presented. After a detailed analysis, these applications can be implemented in cascaded systems, sequentially, parallelly or autonomously. 


\section{Space heating}

Space heating is one of the most popular direct applications of geothermal resources. The earliest known commercial use in district heating was in Chaudes-Aigues Cantal, France in the14th century. Space heating is dominated by district heating systems (Bloomquist 2003). Total installed capacity of space heating is $7602 \mathrm{MW}_{\mathrm{t}}$, which is $36.8 \%$ of the worldwide capacity of geothermal direct use (excluding heat pumps). The annual energy for space heating is $88.7 \mathrm{TJ} /$ year, which is $33.6 \%$ of the total energy used (excluding heat pumps) and is constantly growing (Lund and Boyd 2016). Among ca. 5000 district heating systems in Europe, 250 of them use geothermal energy. Moreover, over $25 \%$ of the EU population live in areas where geothermal district heating can be provided (Sayegh et al. 2017). Poland's contribution to supplying the district heating system is $41 \%$, which is the eighth place among European countries (Sayegh et al. 2017). According to Lund et al. (2014), a new trend is to integrate renewable energy sources into thermal grids and provide low-temperature distribution water $\left(30-70^{\circ} \mathrm{C}\right)$, called as the fourth generation district heating (4GDH). In 2017 in Poland, the total installed geothermal capacity of space heating was ca. 76 $\mathrm{MW}_{\mathrm{t}}$, while the annual geothermal energy production was $868 \mathrm{TJ} /$ year (Kepinska 2018).

Using geothermal energy for heating makes it necessary to analyse not only geological or reservoir factors, but also some technical aspects such as a possibility of constructing or using the already existing district heating network infrastructure for geothermal heating or designing proper low supply/return temperature. For instance, there are some cities in Poland that have a district heating network (geoDH), but in the Mogilno-Lodz trough area, only two are geothermally supplied. Alternatively, if a heating network is not applicable in a given city, some big customers should be considered to use geothermal energy for space heating. The most popular heating supply/return temperatures in Poland are (in ${ }^{\circ} \mathrm{C}$ ): $90 / 70$ and, preferably, $60 / 45$ or even $35 / 28$. Heating efficiency increases in buildings which are properly thermo-modernized and it makes possible to decrease a supply temperature within the building.

Examples of geothermal waters sources and temperatures are given by Glassley (2010). Sources of more than $65{ }^{\circ} \mathrm{C}$ desirable for (small) geothermal systems supplying geothermal water directly to consumers or heat exchangers are needed (e.g., Poland).

In case of the Lower Cretaceous formations, according to Fig. 6, the minimum temperature of ca. $65{ }^{\circ} \mathrm{C}$ is expected at depths of ca. $1500 \mathrm{~m}$, especially in the area of the Mogilno trough and the transition zone. Waters with temperatures higher than $65^{\circ} \mathrm{C}$ can have high mineralization (cf. Fig. 7.). This concerns especially waters from the Mogilno trough, where mineralization of proper waters is ca. $100 \mathrm{~g} / \mathrm{L}$. The best conditions for heating purposes can be found in the transition zone, where waters of temperature $>65^{\circ} \mathrm{C}$ have a lower mineralization level, in the range of $0.4-\mathrm{ca} .25 \mathrm{~g} / \mathrm{L}$.

\section{Balneotherapy and balneorecreation}

Using geothermal waters for treatment has a long history. Geothermal water was used for bathing since the dawn of civilization in many parts of the world (Fridleifsson 2001). Geothermal water was used for bathing and curing of diseases by people for many thousands of years, e.g., in Asia (about 5000 years ago) or by Greeks, Romans and Turks in Europe (Lund 2005). There were many spas in Europe established by Romans. In some countries, like Hungary, geothermal spas are popular tourist attractions (Toth et al. 2015). Nowadays, people visit spas to improve their health and appearance, to get away from stress, work, and to refresh and revitalize both their body and mind (Lund 2005).

Bathing and swimming have the biggest share in direct use of geothermal energy. They are provided in many countries of the world. The total capacity of bathing and swimming worldwide is $9143 \mathrm{MW}_{\mathrm{t}}$, while use is $119,611 \mathrm{TJ} /$ year. This is $44.33 \%$ and $45 \%$, respectively (Lund and Boyd 2016). In Poland, installed capacity for bathing and swimming purposes was estimated to be $10.34 \mathrm{MW}_{\mathrm{t}}$ and annual energy use was $100.4 \mathrm{TJ} /$ year (Kepinska 2015).

Geothermal waters used for bathing and medicinal purposes must satisfy certain standards (qualitative, hygienic, etc.). Besides, waters should satisfy appropriate conditions relating to temperature, mineralization and contents of certain chemical elements (specific elements). Suitability of natural waters from the Mogilno-Lodz trough for medicinal and recreational purposes is estimated based on Kochanski (2002) and legal regulations (Decree of the Ministry of

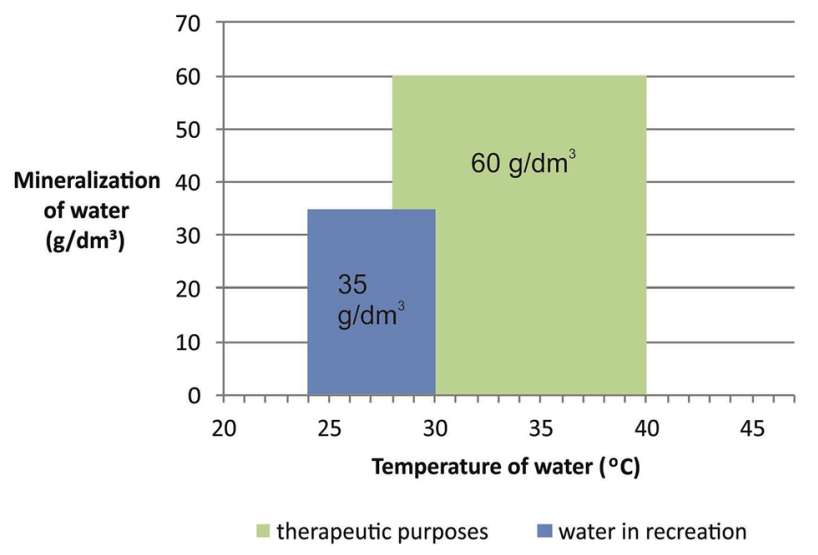

Fig. 8 Temperature and mineralization requirements for therapeutic and recreational use of geothermal waters, based on Kochanski (2002) 
Health, Dz.U.2018.605). In Fig. 8, limits are given for minimum and maximum temperature values, together with the mineralization level of waters convenient for therapeutic and recreational purposes.

Waters in balneotherapy or recreational purposes may not require high temperature, while bathing comfort is connected with human body temperature. Use of geothermal waters for bathing can be accompanied with using them for other applications, where higher temperatures are required. To maintain hygienic standards, a separate part of geothermal water stream intended for different purposes can be used. Partially chilled waters can be used as well.

If we consider direct use of natural geothermal water with certain temperature and mineralization from the source (according to Kochanski 2002), appropriate waters can be expected in the Mogilno trough (Fig. 7). While considering only reservoir temperature for recreation and/or therapy, temperatures $>25{ }^{\circ} \mathrm{C}$ and $28^{\circ} \mathrm{C}$, accordingly, can be expected at depths of ca. $500 \mathrm{~m}$ in the Mogilno trough and in the transition zone. Moreover, waters in these zones have a higher content of specific compounds such as $\mathrm{I}, \mathrm{Br}$ ions and in the transition zone: $\mathrm{Fe}$ ions (cf. Specific compounds section). The Lodz Zone is less prospective for therapeutic purposes, while the content of $\mathrm{Fe}$, I and $\mathrm{Br}$ ions is below the limits of Decree of the Ministry of Health, Dz.U.2018.605 and the Polish Association of Balneology and Physical Medicine (2016).

\section{Mineral extraction}

High concentration of minerals is considered a major engineering challenge during geothermal water exploitation. However, geothermal brines can be the source of valuable minerals or metals (Bloomquist 2006). The most valuable for mineral extraction purposes are waters containing $35-400 \mathrm{~g} / \mathrm{L}$ of salts (Svalova 2010).

Mineral extraction is categorized as an industrial process and a direct use of geothermal energy. It is carried out in several countries, mostly from Eastern Europe such as Bulgaria, Russia and Poland for chemical extraction and Vietnam for iodine and salt extraction (Lund and Boyd 2016). Iodine-bromine salts are also extracted in Poland for therapeutic purposes (Kepinska 2015). There are also some studies on use of byproducts of desalination technology for, i.e., balneological purposes (Tomaszewska and Szczepański 2014).

Geothermal waters from the Mogilno-Lodz trough have been analysed in terms of being potential source of certain minerals extraction, such as $\mathrm{I}, \mathrm{Br}, \mathrm{K}$ or $\mathrm{Mg}$. The results of the chemical analysis of $\mathrm{K}$ and $\mathrm{Mg}$ are presented as an Electronic Supplement Material. Minerals must be concentrated in an adequate amount: $18 \mathrm{mg} / \mathrm{L}$ for I ions, $250 \mathrm{mg} / \mathrm{L}$ for $\mathrm{Br}$ ions, $350 \mathrm{mg} / \mathrm{L}$ for $\mathrm{K}$ ions and $2000 \mathrm{mg} / \mathrm{L}$ for $\mathrm{Mg}$ ions
(Dzieniewicz 1990). Despite large depths and high values of mineralization for some waters, only in one sample there is suitable accumulation of minerals, enabling industrial exploitation. In case of water sample from this well, $\mathrm{K}$ ions occurred in the amount of $350 \mathrm{mg} / \mathrm{L}$. The sample is from the Mogilno trough. The other maximum contents: $12.8,86$ and $567 \mathrm{mg} / \mathrm{L}$ for I, $\mathrm{Br}$ and $\mathrm{Mg}$, respectively, do not achieve the limits. Unfortunately, there is no analysis concerning, e.g., rare minerals. Minerals occurring in geothermal waters of the Mogilno-Lodz trough might also be used for the production of salts applicable for medicinal or recreational bathing purposes, and the production of cosmetics based on geothermal waters.

\section{Electric power generation applying low-temperature geothermal waters (binary systems)}

The possibility of geothermal power generation applying binary schemes is addressed in this paper because of noticeable global interest and developments of this technology nowadays. This technology was first applied 50 years ago in Kamchatka, Russia (Franco and Vaccaro 2016). The capacity of 1790 installed geothermal binary power plants is $1726 \mathrm{MW}_{\mathrm{e}}$, which is $14 \%$ of the total installed capacity of geothermal plants in 26 countries (Bertani 2016). Binary units are usually smaller than other standard geothermal plant units. An average capacity of binary unit is $6.3 \mathrm{MW}_{\mathrm{e}} /$ unit and average energy is $31 \mathrm{GWh} / \mathrm{unit}$, while in the most popular single flash unit these average values are $30.4 \mathrm{MW}_{\mathrm{e}} /$ unit and $179 \mathrm{GWh} /$ unit, respectively (Bertani 2016).

The prospective development of the binary technology increases an interest in medium to low-temperature geothermal resources (Franco and Vaccaro 2016). Binary plants may be more efficient than single or double flash plants (IRENA 2017; Gallup 2009) for a lower enthalpy range (750-850 kJ/ kg) (Zarrouk and Moon 2014, 2015; DiPippo 2015a). Binary and flash-steam plants operate over a wide range of geofluid exergy (DiPippo 2015b).

In Poland, electric power is generated mostly from coal. Other sources still have a small share; however, electric power generated from renewable energy sources is growing in recent years. Poland does not have high-temperature geothermal resources $\left(>150^{\circ} \mathrm{C}\right)$, suitable for standard electric power generation when electric power is generated by, i.e., direct suppling with geothermal high-temperature fluid in direct dry steam plants or in flash plants (IRENA 2017; Barbier 2002).

Binary systems are regarded as the best systems for energy conversion, using medium- and low-temperature geothermal systems, both from the technical and the environmental point of view (Franco and Villani 2009). Usually, geothermal water temperatures above $80-90{ }^{\circ} \mathrm{C}$ (Bujakowski 
and Tomaszewska et al. 2014) are indicated as a minimum to consider electric power generation using binary technology, taking into account energetic and economic aspects. Some potential locations for binary installations in Poland were given in (Bujakowski and Tomaszewska et al. 2014), but they are related to the geothermal aquifers connected with Lower Jurassic formations which have better thermal parameters than Lower Cretaceous formations.

According to Figs. 6 and 7, there are few samples, for which reservoir temperature exceeds $70{ }^{\circ} \mathrm{C}$ in Lower Cretaceous formations. It means that these are not favourable conditions for standard binary systems development in Lower Cretaceous formations. Waters from Lower Cretaceous formations at such depths have diversified mineralization. And mineralization ranging from typically 25 to even $100 \mathrm{~g} / \mathrm{L}$ would be expected at depths below $2000 \mathrm{~m}$ (cf. Table 2).

At lower temperatures $\left(80-100{ }^{\circ} \mathrm{C}\right)$, installations with direct evaporation of fluid in an exchanger (Underground Closed Geothermic Heat Exchanger) might be considered (Kaczmarek 2011). Such installations use different working fluids and geothermal heat (geothermal exchangers).

Electric power achieved from such installations in the Lower Cretaceous formation with maximum temperature of ca. $70{ }^{\circ} \mathrm{C}$ would be small. Assuming circulation of $1 \mathrm{~kg} / \mathrm{s}$ of isobutane working fluid (based on Kaczmarek 2011), the calculated power is $32 \mathrm{~kW}$, with $\eta=10 \%$ efficiency (in laboratory environment). Temperature occurring in the Lower Cretaceous formations is too low. Nevertheless, if considered, the binary installation should be preceded by adequate energetic and economic analysis.

\section{Aquifer thermal energy storage (ATES)}

Energy storage is a key element of the modern energy supply chain to, e.g., improve efficiency of energy systems or renewable energy sources use (Aneke and Wang 2016). For thermal energy storage (TES), different storage media and temperature ranges are in place. For heating or cooling of buildings, mostly low-temperature thermal energy storage (LTTES) applications, which operate below $200{ }^{\circ} \mathrm{C}$ are used (Fernandes et al. 2012).

Aquifer thermal energy storage systems (ATES) use geothermal resources with low-temperature geological waterbearing formations to provide a buffer to balance fluctuations in heat and/or cold supply and demand (Lee 2014, 2010; Vanhoudt et al. 2011; Bridger and Allen 2005). There are ca. 3000 ATES systems in operation worldwide, with total heat and cold production of $2.5 \mathrm{TWh} /$ year (Fleuchaus 2018).

In ATES, groundwater is used to carry thermal energy in and out an aquifer using wells (Paksoy 2007), typically at depths of tens up to hundreds of meters. In ATES, the aquifer can be used for waste heat storage. Thus, energy is not lost, while storage heat increases water temperature in the aquifer. Therefore, in the heating season, water with higher temperature can be used, thus, increasing heating performance (Bridger and Allen 2014). It is also possible to use high-temperature ATES systems (HT-ATES) for heating (Vanhoudt et al. 2011; Sanner et al. 2005). However, only a few HT-ATES systems (with operational temperature $>50{ }^{\circ} \mathrm{C}$ ) have been installed, because of higher costs and lower efficiencies than in case of low-temperature systems (Kranz et al. 2015). In high-temperature systems, management of waste heat from, e.g., a cogeneration unit in an ATES system is possible even at depths of $1200-1300 \mathrm{~m}$ (Seibt and Kabus 2006).

As the studied Lower Cretaceous formations lay at various depths of the study area, shallower depths were preferred. Areas where the Lower Cretaceous formations lay at depths lower than $1500 \mathrm{~m}$ were selected. Other parameters that were assigned to determine favourable areas are presented in Fig. 9. As there are not many studies dedicated to thermal energy storage and not enough data from wells of the Mogilno-Lodz trough, input data were taken from modelling data of Gorecki et al. (2006) to provide a general assessment of the area. The aquifers with flow rate between 10 and $100 \mathrm{~m}^{3} / \mathrm{h}$ where chosen. The reservoir thickness taken into consideration is ca. $30 \mathrm{~m}$. The map is a result of the intersection of mentioned parameters. The selected areas, which satisfy the boundary conditions, are shown in Fig. 9.

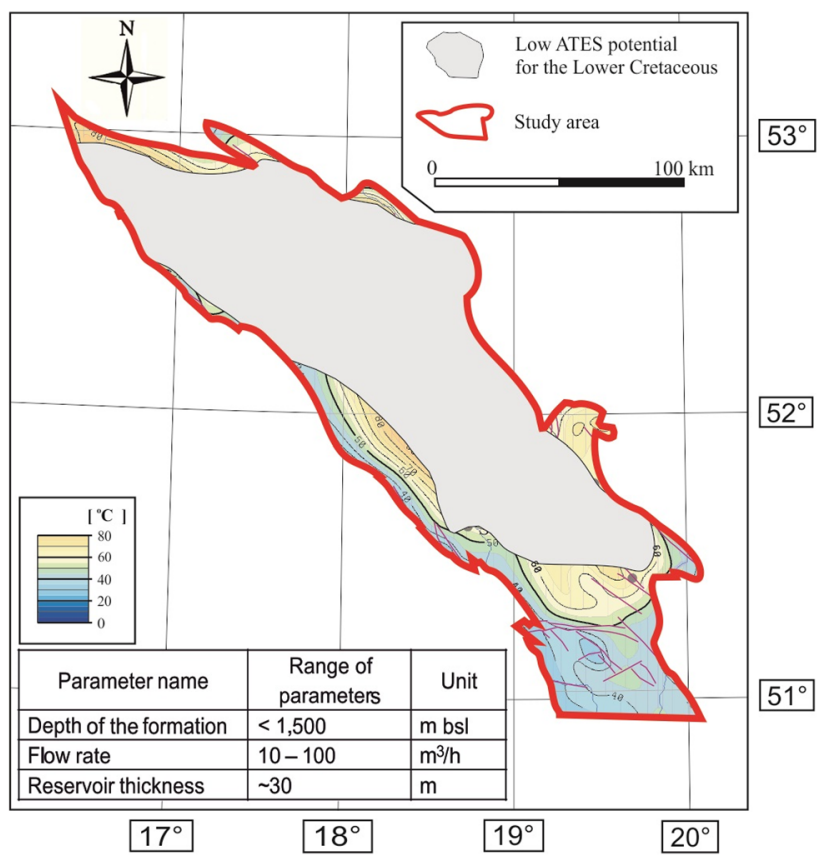

Fig. 9 Map of potential areas for applying aquifer thermal energy storage (ATES) on the layer showing temperature in the Lower Cretaceous formations top. Initial parameters in the table after Seibt and Kabus (2006), the temperature layer based on Gorecki et al. (2006) 
For the areas with the best conditions on the map in Fig. 9, temperature ranges in the reservoir from Gorecki et al. (2006) were also drawn. Generally, the best conditions for ATES in the Lower Cretaceous formations are located in the southern and marginal parts of the trough. However, exact locations of such installations should be carefully tested for detailed geology, groundwater flow parameters, permeability of the aquifer and chemical composition of water, etc.

It is also possible to use aquifers to store energy coming from other types of renewable energy sources, i.e., solar collectors or cogeneration (biomass) units in periods of the year/month when the surplus of produced energy would normally be lost. This is because of the specific nature of some renewable energy sources, which are the most easily available when there is a lower demand for heating (like solar energy in summer). Similarly, waste heat from different types of processes, such as industrial ones or from space cooling, normally not utilized, can be stored in the aquifer and increase efficiency of further space heating and increase the flexibility of the energy system. In this case, it is essential to associate with a suitable adjacent heat producer. For ATES applications, thermal energy storage in systems with heat pumps is popular. Moreover, geothermal energy can be used in GSHP separately as well as in other processes which require thermal energy, such as drying of different products, aquaculture or other industrial processes possible to be applied in the Mogilno-Lodz trough.

\section{Conclusions}

A simple estimation procedure for hydrogeological information, such as water mineralization and geothermal conditions of the reservoir obtained from archival chemical analysis and borehole temperature loggings was developed within this paper. Preliminary feasibilities of different geothermal applications were evaluated for the Lower Cretaceous formations in the Mogilno-Lodz trough (the Polish Lowlands). In the area, there are low-temperature geothermal conditions and highly variable mineralization of geothermal waters. According to the available data, waters occurring in the area of the Mogilno-Lodz trough in the Lower Cretaceous formations are mostly of $\mathrm{Na}-\mathrm{Cl}$ type (the Mogilno trough and transition zone) and $\mathrm{Na}-(\mathrm{Ca})-\mathrm{HCO}_{3}$ type in the $\mathrm{Lodz}$ trough. Waters contain some specific elements (I, Br, Fe). The highest mineralization values exceed $90 \mathrm{~g} / \mathrm{L}$ and are related probably to salt structures. A geothermal gradient in the Lower Cretaceous formations is $2.5^{\circ} \mathrm{C} / 100 \mathrm{~m}$ on average and at certain depths of the Lower Cretaceous formations, the reservoir temperature exceeds $70{ }^{\circ} \mathrm{C}$.

The potential of geothermal applications has been estimated for three trough zones. Possibilities of conjunctive geothermal applications, such as space heating, balneotherapy and balneorecreation, mineral extraction, electricity production in binary systems and aquifer thermal energy storage (ATES) were examined in the Lower Cretaceous formations. Geothermal waters can be used for heating, balneotherapeutical, recreational and other purposes. There is no potential for binary systems. It may be possible in some areas to produce electricity from geothermal energy of given temperatures in a binary system, but in very small amounts (tens of $\mathrm{kW}$ ) and at greater depths, where the temperature is higher. There is a potential for the ATES application in S and SW of the study area. Minerals' extraction has a lower potential in this area.

Presented zones demonstrate low enthalpy geothermal energy resources. Despite lower temperature of waters, such resources can be a high-quality source of energy with low $\mathrm{CO}_{2}$ emission to the atmosphere. Moreover, geothermal waters of the Lower Cretaceous in the Mogilno-Lodz trough can create various products and be used for diverse purposes.

Acknowledgements Funding was provided by Akademia GórniczoHutnicza im. Stanislawa Staszica (Grant no. 11.11.140.704).

Open Access This article is distributed under the terms of the Creative Commons Attribution 4.0 International License (http://creativeco mmons.org/licenses/by/4.0/), which permits unrestricted use, distribution, and reproduction in any medium, provided you give appropriate credit to the original author(s) and the source, provide a link to the Creative Commons license, and indicate if changes were made.

\section{References}

Aneke M, Wang M (2016) Energy storage technologies and real life applications-a state of the art review. Appl Energy 179:350-377. https://doi.org/10.1016/j.apenergy.2016.06.097

Axelsson G (2010) Sustainable geothermal utilization-case histories; definitions; research issues and modelling. Geothermics 39:283291. https://doi.org/10.1016/j.geothermics.2010.08.001

Barbier E (2002) Geothermal energy technology and current status: an overview. Renew Sust Energy Rev 6:3-65. https://doi. org/10.1016/S1364-0321(02)00002-3

Bertani R (2016) Geothermal power generation in the world 2010-2014 update report. Geothermics 60:31-43. https://doi.org/10.1016/J. GEOTHERMICS.2015.11.003

Bloomquist RG (2003) Geothermal space heating. Geothermics 32:513-526. https://doi.org/10.1016/j.geothermics.2003.06.001

Bloomquist RG (2006) Economic benefits of mineral extraction from geothermal brines. GRC Trans 30:579-582

Bojarski L, Plochniewski Z, Stachowiak J (1976) Thermal waters of the Polish. Lowl Geol Quart 20(3):657-672

Bridger DW, Allen DM (2005) Designing aquifer thermal energy storage systems. ASHRAE J 47(9):32-38

Bridger DW, Allen DM (2014) Influence of geologic layering on heat transport and storage in an aquifer thermal energy storage system. Hydrogeol J 22:233-250. https://doi.org/10.1007/s1004 0-013-1049-1

Buday T, Szücs P, Kozák M, Püspöki Z, McIntosh BW, Bódi E, Bálint B, Bulátkó K (2015) Sustainability aspects of thermal water production in the region of Hajduszoboszlo-Debrecen, Hungary. 
Environ Earth Sci 74:7511-7521. https://doi.org/10.1007/s1266 5-014-3983-1

Bujakowski W, Tomaszewska B et al (2014) Atlas of the possible use of geothermal waters for combined production of electricity and heat using binary systems in Poland, Wydawnictwo "Jak", Krakow

Dadlez R (2001) Mid-Polish trough-geological cross-sections. Państwowy Instytut Geologiczny, Warsaw

Dadlez R, Marek S, Pokorski J (2000a) Geological map of Poland without Cainozoic deposits. Polish Geological Institute, Warsaw

Dadlez R, Iwanow A, Papiernik B (2000b) Mapa strukturalna stropu wapienia muszlowego. In: Kotarba M (ed) Potential and the balance of generating dolomite deposits in the main Permian basin of Poland. CAG, Warsaw

Decree of Minister for Health of 13 April 2006 on the scope of the studies necessary to determine the therapeutic properties of natural materials and healing properties of climate, the criteria for their evaluation and the model certificate confirming these properties (Dz.U.2018.605)

DiPippo R (2015a) Comments on "Efficiency of geothermal power plants: a worldwide review" by Sadiq J. Zarrouk and Hyungsul Moon. Geothermics 53:548-550. https://doi.org/10.1016/j.geoth ermics.2014.06.006

DiPippo R (2015b) Geothermal power plants: evolution and performance assessments. Geothermics 53:291-307. https://doi. org/10.1016/j.geothermics.2014.07.005

Dowgiallo J (2012) Occurrence and use of mineral and thermal waters in Poland. Environ Earth Sci 67:2251-2259. https://doi. org/10.1007/s12665-012-1666-3

Dowgiallo J, Kaczor D, Porowski A (2007) Thermal brines of the Polish Lowlands. Contemp Hydrol Probl XIII 2:53-63

Dzieniewicz M (1990) Possibilities of using geothermal waters as a material for production of iodine, bromiene and other elements. In: Sobon J, Was M (eds) Possibilities of the utilization of geothermal Walters in Poland with special regard to the MogilnoLodz Synclinorium, Department of Fossil Fuels, AGH-UST; Geosynoptics Society GEOS, Slesin

Erkan K, Holdmann G, Benoit W, Blackwell D (2008) Understanding the Chena Hot Springs, Alaska, geothermal system using temperature and pressure data from exploration boreholes. Geothermics 37:565-585. https://doi.org/10.1016/j.geothermics.2008.09.001

Fernandes D et al (2012) Thermal energy storage: "How previous findings determine current research priorities". Energy 39:246-257. https://doi.org/10.1016/j.energy.2012.01.024

Fleuchaus P et al (2018) Worldwide application of aquifer thermal energy storage-a review. Renew Sustain Energy Rev 94:861876. https://doi.org/10.1016/j.rser.2018.06.057

Franco A, Vaccaro M (2016) Recent trends in research and application of ORC plants for geothermal energy use. In: Proceedings of the European geothermal congress 2016, Strasbourg, France, pp 1-10

Franco A, Villani M (2009) Optimal design of binary cycle power plants for water-dominated medium-temperature geothermal fields. Geothermics 38:379-391. https://doi.org/10.1016/j.geoth ermics.2009.08.001

Fridleifsson IB (2001) Geothermal energy for the benefit of the people. Renew Sust Energy Rev 5:299-312

Gallup D (2009) Production engineering in geothermal technology: a review. Geothermics 38:326-334. https://doi.org/10.1016/j.geoth ermics.2009.03.001

Glassley WE (2010) Geothermal energy. Renewable energy and the environment. CRC Press Taylor and Francis Group, Boca Raton

Gorecki W et al (1995) Atlas of the geothermal waters of Polish Lowlands. ISE AGH, Krakow

Gorecki W et al (2006) Atlas of geothermal resources of Mesozoic formations in the Polish Lowlands, Department of Fossil Fuels, AGH-UST, Krakow
Gorecki W, Sowizdzal A, Hajto M, Wachowicz-Pyzik A (2015) Atlases of geothermal waters and energy resources in Poland. Environ Earth Sci 74:7487-7495

Halaj E (2015) Geothermal bathing and recreation centres in Poland. Environ Earth Sci 74:7497-7509. https://doi.org/10.1007/s1266 5-014-3740-5

Halaj E (2018) Characteristics and sustainable utilisation prospects of geothermal waters of the liassic formations in the MogilnoLodz trough, Poland. Sustain Water Resour Manag. https://doi. org/10.1007/s40899-018-0235-7

http://www.geoDH.eu. Accessed 26 July 2018

IRENA (2017) Geothermal power: technology brief, international renewable energy agency, Abu Dhabi. http://www.irena.org/-/ media/Files/IRENA/Agency/Publication/2017/Aug/IRENA Geothermal_Power_2017.pdf. Accessed 26 July 2018

Kaczmarek R (2011) Application of installation with direct evaporation of working medium in the geothermic heat exchanger to supplying the geothermic power plants. Geol Explor Technol Geotherm Sustain Dev 1-2:189-198

Kepinska B (2015) Geothermal energy country update report from Poland, 2010-2014. In: Proceedings world geothermal congress 2015, Melbourne, Australia, 19-25 April 2015, pp 1-11

Kepinska B (2018) A review of geothermal energy uses in Poland in 2016-2018. Technika Poszukiwań Geologicznych. Geotermia, Zrównoważony Rozwój 1 (in print)

Kepinska B et al (2017) Study Visits' Report. The EEA Project Geothermal energy - a basis for low-emission heating, improving living conditions and sustainable development-preliminary studies for selected areas in Poland. http://www.eeagrants.agh. edu.pl. Accessed 26 July 2018

Kochanski JW (2002) Balneotherapy and hydrotherapy. Wydawnictwo AWF we Wroclawiu, Wroclaw

Kranz S et al (2015) Improving aquifer thermal energy storage efficiency. In: Proceedings world geothermal congress 2015, Melbourne, Australia, 19-25 April 2015

Lee KS (2010) A review on concepts, applications, and models of aquifer thermal energy storage systems. Energies 3:1320-1334. https://doi.org/10.3390/en3061320

Lee KS (2014) Effects of regional groundwater flow on the performance of an aquifer thermal energy storage system under continuous operation. Hydrogeol J 22:251-262. https://doi.org/10.1007/ s10040-013-1052-6

Lo Russo S, Civita MV (2009) Open-loop groundwater heat pumps development for large buildings: a case study. Geothermics 38:335-345. https://doi.org/10.1016/j.geothermics.2008.12.009

Lo Russo S, Taddia G, Baccino G, Verda V (2011) Different design scenarios related to an open loop groundwater heat pump in a large building: impact on subsurface and primary energy consumption. Energy Build 43:347-357. https://doi.org/10.1016/j. enbuild.2010.09.026 (ISSN 0378-7788)

Lund JW (2005) Basic principles of geothermal balneology and examples in the United States. In: Proceedings world geothermal congress 2005, Antalya, Turkey, 24-29 April 2005

Lund JW (2006) Chena hot springs. GHC Quarterly Bulletin 27(3):2-4

Lund JW, Boyd TL (2016) Direct utilization of geothermal energy 2015. Worldw Rev Geotherm 60:66-93. https://doi.org/10.1016/j. geothermics.2015.11.004

Lund et al (2014) 4th generation district heating (4GDH): integrating smart thermal grids into future sustainable energy systems. Energy 68:1-11. https://doi.org/10.1016/j.energy.2014.02.089

Luo J, Rohn J, Bayer M, Priess A, Wilkmann L, Xiang W (2015) Heating and cooling performance analysis of a ground source heat pump system in Southern Germany. Geothermics 53:57-66. https ://doi.org/10.1016/j.geothermics.2014.04.004 
Paksoy H (2007) Thermal energy storage for sustainable energy consumption. Fundamentals, case studies and design. Springer, Amsterdam

Petersen K, Lerche I (1995) Quantification of thermal anomalies in sediments around salt structures. Geothermics 24(2):253-268

Plewa S (1994) Distribution of geothermal parameters on the territory of Poland. Wydawnictwo CPPGSMiE PAN, Krakow

Recommendations Polish Association of Balneology and Physical Medicine in Terms of Changes in the Classification of Therapeutic Waters (2016) Polish Association of Balneology and Physical Medicine

Rubio-Maya C, Ambríz Díaz VM, PastorMartínez E, Belman-Flores JM (2015) Cascade utilization of low and medium enthalpy geothermal resources—a review. Renew Sust Energ Rev 52:689-716. https://doi.org/10.1016/j.rser.2015.07.162

Sanner B, Kabus F, Seibt P, Barels S (2005) Underground thermal energy storage for the German Parliament in Berlin, system concept and operational experiences. In: Proceedings of world geothermal congress 2005, Antalya, Turkey

Sayegh MA et al (2017) Trends of European research and development in district heating technologies. Renew Sustain Energy Rev 68:1183-1192. https://doi.org/10.1016/j.rser.2016.02.023

Schoeller H (1962) Les eaus souterrians Masson et. Cie, Paris

Seibt P, Kabus F (2006) Aquifer thermal energy storage-projects implemented in Germany. In: Proceedings, Ecostock, Richard Stockton College of New Jersey, pp 1-8

Sowizdzal A (2016) Possibilities of petrogeothermal energy resources utilization in central part of Poland. Appl Ecol Environ Res 14(2):555-574. https://doi.org/10.15666/aeer/1402_555574

Svalova (2010) Mineral extraction from brines and geothermal resources complex use in Russia. In: Proceedings world geothermal congress 2010, Bali, Indonesia, 25-29 April 2010
Szanyi J, Kovács B (2010) Utilization of geothermal systems in SouthEast Hungary. Geothermics 39:357-364. https://doi.org/10.1016/j. geothermics.2010.09.004

Szewczyk J, Hajto M (2006) Heat flow versus sub-surface temperatures in the Polish Lowlands. In: Gorecki W (ed) Atlas of geothermal resources of Mesozoic formations in the Polish Lowlands, Department of Fossil Fuels, AGH-UST, Krakow

Taylor L, Water M, Krumdieck S (2013) Development of a low temperature geothermal Organic Rankine Cycle standard. In: Proceedings of 35th New Zeland geothermal workshop, 17-20 November 2013, Rotorua, New Zeland, pp 1-8

Tomaszewska B, Szczepański A (2014) Possibilities for the efficient utilisation of spent geothermal waters. Environ Sci Pollut Res 21:11409-11417. https://doi.org/10.1007/s11356-014-3076-4

Toth A et al (2015) Social acceptance of geothermal energy through tourism and balneology. In: Proceedings World Geothermal Congress 2015 Melbourne, Australia, 19-25 April 2015

Vanhoudt D, Desmedt J, Van Bael J, Robeyn N, Hoes H (2011) An aquifer thermal storage system in a Belgian hospital: long-term experimental evaluation of energy and cost savings. Energy Build 43(12):3657-3665. https://doi.org/10.1016/j.enbuild.2011.09.040

Wisniewski S, Nowak W, Borsukiewicz-Gozdur A (2011) Influence of ORC power plant type on effectiveness of geothermal water utilization (from the Lower Triassic aquifer). Geol Explor Technol Geotherm Sustain Dev 1-2:157-175

Zarrouk SJ, Moon H (2014) Efficiency of geothermal power plants: a worldwide review. Geothermics 51:142-153. https://doi. org/10.1016/j.geothermics.2013.11.001

Zarrouk SJ, Moon H (2015) Response to the comments by Ronald DiPippo on efficiency of geothermal power plants: a worldwide review. Geothermics 53:550-553. https://doi.org/10.1016/j.geoth ermics.2014.08.009 